\title{
TYÖSSÄ JATKAMINEN JA ELÄKKEELLE SIIRTYMINEN IKÄÄNTYVIEN TYÖNTEKIJÖIDEN POHDINNOISSA
}

\section{Johdanto}

Suomessa työntekijät siirtyvät eläkkeelle vieläkin melko varhain, vaikka työurien pidentäminen ja eläköitymisen myöhentäminen onkin ollut viime vuosikymmeninä maassamme yksi keskeinen yhteiskuntapoliittinen (ks. Järnefelt ym. 2014) ja samalla kuntoutuksen tavoite (STM 2016). Tilastotietojen mukaan työurien pituus on kuitenkin ollut vähitellen kasvava. Vuonna 2015 eläkkeellesiirtymisiän odote työeläkejärjestelmässä oli 61,1 vuotta, mikä on 0,1 vuotta laskua edellisvuodesta. Vastaava luku vuonna 2005 oli 59,1 vuotta. (Kannisto 2016.)

Eläkkeellesiirtymisaikeita on tutkittu runsaasti erilaisista teoreettisista näkökulmista monilla tieteenaloilla. Eläkkeelle siirtymistä on tutkittu esimerkiksi päätöksentekoprosessina, rooli- ja identiteetin muutoksen sekä rationaalisen valinnan teorian näkökulmista (Beehr 1986, Dufva 2012, ks. myös Schalk ym. 2010, Wang \& Shi 2014). Varhaisemmat eläkkeelle siirtymisen selittäjät keskittyivät lähinnä yksilötason ilmiöihin joko kielteisinä työelämästä työntävinä (push) tai myönteisinä eläkkeelle vetävinä (pull) tekijöinä ja niiden vaikutukseen yksilön eläköitymispäätökseen (esim. Beehr 1986, Shultz ym. 1998). Uusimmissa tutkimuksissa on jatkettu tätä dikotomista tarkastelua (van Solinge \& Henkens 2014) kiinnittäen huomiota esimerkiksi perhetilanteen tai johtamisen (Dufva 2012,
Järnefelt ym. 2014) merkitykseen. Suomessa vuonna 2005 tapahtuneen eläkeuudistuksen jälkeen tutkimuksen näkökulma laajeni työssä jatkamisen kysymyksiin, kun eläkepolitiikan tavoitteeksi tuli työurien pidentäminen; kiinnostuksen kohteena ovat olleet erityisesti tekijät, jotka vaikuttavat työssä jatkamiseen vanhuuseläkeikään saakka tai sen alarajan yli (Pekka 2010, Takala ym. 2010).

Työurien pidentyminen edellyttää työntekijöiltä riittävää työkykyä ja jaksamista. Työurien jatkamista koskevien asenteiden muutoksen lisäksi koetussa työkyvyssä on havaittu myönteistä kehitystä (Kauppinen ym. 2013). Enemmän kuin neljä viidesosaa 30-64-vuotiaista ja yli puolet 65-74-vuotiaista arvioi itsensä täysin työkykyiseksi vuonna 2011 Terveys, toimintakyky ja hyvinvointi -tutkimuksessa (Gould ym. 2012). Samassa tutkimuksessa 45-74-vuotiaista miehistä kuntoutusta arvioi tarvitsevansa noin neljännes ja naisista lähes kolmannes (Pensola ym. 2012). Tulevaisuudessa väestön ikärakenteesta ja työelämän erilaisista muutoksista johtuen työkykyä uhkaavien tekijöiden on ennakoitu säilyvän tai jopa lisääntyvän. Työkyvyn heikkenemisen riskitekijöistä suuri osa on senkaltaisia, että niihin sekä voidaan että kannattaa puuttua. (Pasternack ym. 2015.)

Kuntoutus on ollut Suomessa keskeinen keino edistää työssä jaksamista ja ylläpitää työkykyä (Aalto ym. 2015). Jaana Kuoppalan 
ja Anne Lamminpään (2008) systemaattisen kirjallisuuskatsauksen mukaan erilaisilla varhaisvaiheen kuntoutuksilla on vaikutusta, kun taas työkyvyn alenemisen lisääntyessä tarvitaan erilaisten kuntoutusmuotojen yhdistämistä. Työpaikan integrointia kuntoutukseen on pidetty välttämättömänä keinona pidentää työuria (Hinkka ym. 2015). Kuntoutuksen vaikuttavuustutkimuksessa on katsottu ongelmalliseksi, että vaikuttavuutta on seurattu vain muutaman vuoden päähän interventiosta (Tuloksellisuustarkastuskertomus 2013; ks. myös esim. Vartiainen 2009), joten luotettavaksi katsottua näyttöä työurien pitenemiseen ei nähdä olevan (Aalto ym. 2002).

Suomalaisessa KELA:n ammatillisen kuntoutuksen järjestelmässä on viime vuosina tapahtunut muutoksia: ASLAK-kuntoutuksesta luovuttiin vuoden 2015 lopussa eikä tilalle kehitettyä AURA-kuntoutusta (ks. esim. Seppänen-Järvelä ym. 2015) päästy koskaan aloittamaan. Myös työkykyä ylläpitävän ja parantavan TYK-kuntoutuksen myöntäminen on lopetettu. Tilalle luotu KIILA-kuntoutus edellyttää työkyvyn heikentymistä, ja se suunnitellaan yksilöllisesti yhteistyössä työnantajan kanssa. (Ammatillinen KIILA-kuntoutus työssäoleville; Vainiemi 2015.) Kuntoutusjärjestelmän muutosta on myös edessä, sillä kuntoutuksen uudistamiskomitean aikajänne ulottuu ainakin syksyyn 2017 (STM 2016). Uudistuksen lähtökohtana ovat olleet kuntoutuksen järjestämisen ja rahoittamisen kysymysten lisäksi yksilöiden erilaiset kuntoutustarpeet.

Tässä artikkelissa analysoidaan kategoria-analyysin keinoin sitä, millaisina ikääntyvät haastateltavat näkevät itsensä eläkkeelle jääjinä tai työssä jatkajina. Tavoitteena on ymmärtää näitä ilmiöitä yksilöiden näkökulmista. Lisäksi tarkastellaan, miten työkykyyn, terveyteen tai kuntoutukseen liittyvät teemat tulevat esille haastattelupuheissa. Kategoriaanalyysiä on hyödynnetty muun muassa ikäkategorioiden (Nikander 2002) ja pitkäaikaistyöttömyyden (Välimaa 2011) tutkimuksessa, mutta tiedonhakumme ei tavoittanut tutkimusta, jossa menetelmää olisi käytetty eläköitymisen tai työurien jatkamisen tutkimiseen.

\section{Eläkkeelle jääminen ja työssä jatkaminen tutkimuskohteena}

Yksilöä työelämästä eläkkeelle työntävät voimat muodostuvat organisaatioon, työrooliin tai työympäristöön liittyvistä kielteisistä tekijöistä. Vastaavasti eläkeläisrooliin liittyvät myönteiset piirteet vetävät yksilöä pois työelämästä. (Ks. esim. Beehr 1986, Shultz ym. 1998, Barnes-Farrell 2003.) Usein työelämästä työntävät tekijät ovat eläköitymispäätökseen vahvemmin vaikuttavia (Shultz ym. 1998). Janet Barnes-Farrell (2003) tuo esille mahdollisuuden soveltaa työntävien ja vetävien tekijöiden tarkastelua työroolissa pysymisen ja työelämässä jatkamisen näkökulmasta. Päätös jatkaa työelämässä on työntävien ja vetävien voimien punninnan lopputulos.

Aikaisemman tutkimuksen mukaan eläkkeellesiirtymispäätöstä ennakoivat vahvasti yksilön henkilökohtaiset tekijät, kuten terveys ja taloudellinen tilanne (Beehr 1986, BarnesFarrell 2003, Gaillard \&t Desmette 2008, Dufva 2012). Samat syyt on todettu tärkeimmiksi myös työssä jatkamista harkittaessa (Perkiö-Mäkelä ym. 2012). Usein tärkein eläkkeelle työntävä tekijä on kuitenkin työntekijän heikentynyt terveys tai työkyky (Salokangas ym. 2005, Shultz \& Wang 2007, Karisalmi ym. 2008, De Wind ym. 2013). Terveydentilan ja työkyvyn parantuessa myös eläkkeelle siirtyminen myöhentyy (mm. Huuhtanen \&t Tuomi 2006, von Bonsdorff 2009, Järnefelt 2010, Perhoniemi 2016). Kansainvälisissä tutkimuksissa on saatu myös päinvastaisia tuloksia: Astrid de Wind kollegoineen (2013) totesi hyvän terveyden vaikuttaneen varhaiseen eläköitymiseen.

Myös ikä ja koulutus ovat yhteydessä eläkkeellesiirtymispäätökseen: mitä iäkkäämpi, sitä halukkaampi yksilö on jäämään eläkkeelle, sen sijaan korkea koulutus ennakoi todennäköisyyttä jatkaa työssä vanhuuseläkeikään (Järnefelt 2010) tai 63 ikävuoden jälkeen (Tuominen ym. 2010). Työntekijän sosioekonomisella asemalla on myös yhteyttä eläkkeelle jäämisen aikeisiin. Noora Järnefeltin ja kumppaneiden (2014) tutkimuksessa ylemmät toimihenkilöt ennakoivat muita useammin myö- 
hempää eläkkeelle jäämistä (myös Perkiö-Mäkelä ym. 2012). Eläkkeelle siirtymisen ajatusten on todettu olevan myös sukupuoliriippuvaisia (mm. von Bonsdorff ym. 2009), tosin asiasta on saatu ristiriitaisia tuloksia (Gaillard Et Desmette 2008). Esimerkiksi Jean A. Talaga ja Terry A. Beehr (1995) totesivat miesten eläköityvän naisia aikaisemmin, mutta hoivarooli perheessä oli yhteydessä naisten varhaiseen eläköitymiseen. Monika E. von Bonsdorffın (2009) tutkimuksessa yksin asuvilla naisilla eläkeaikeita oli vähemmän, työllä oli yksinelävien naisten hyvinvointia ja jatkuvuuden tunnetta ylläpitävä merkitys. Vastaavasti parisuhteessa elämisen on todettu olevan yhteydessä varhaisiin eläkeaikeisiin (Tuominen ym. 2010).

Johtamisen ja työntekijöiden eläkkeelle siirtymisen yhteyttä on tutkittu lisääntyvästi (esim. von Bonsdorff 2009, Laine ym. 2010, Manka \&t Nuutinen 2013, Järnefelt ym. 2014, van Solinge \&t Henkens 2014). Työntekoon motivoivan, innostavan ja työntekijöitä tukevan johtamistavan (esim. Laine ym. 2010, van Solinge \& Henkens 2014) on koettu edistävän työssä jatkamista. Järnefeltin ja kumppaneiden (2014) tutkimuksessa erityisen merkityksellistä työssä jatkamiselle oli eri-ikäisten tasapuolinen kohtelu, mikä liittyy oikeudenmukaiseen johtamiseen (Lind \& Tyler 1988). Vastaavasti epäoikeudenmukaiseksi koetun johtamisen on todettu lisäävän eläköitymisajatuksia (Heponiemi ym. 2008, Sulander ym. 2016). Marja-Liisa Mankan ja Sanna Nuutisen (2013) tutkimuksessa työyhteisön toimivuus ja ilmapiiri olivat keskeisiä työssä jatkamiseen kannustavia tekijöitä (myös Laine ym. 2010, Pekka 2010). Seuraavaksi eniten työssä jatkamista edistivät mielekkäät työtehtävät, lähijohdon tuki ja kannustus sekä palkitsemisjärjestelmä. Kerstin G. Reeuwijk tutkijaryhmineen (2013) havaitsi eläkkeelle työntävinä tekijöinä osaamisen puutteellisen hyödyntämisen sekä haluttomuuden koulutukseen ja osaamisen lisäämiseen. Työn stressaavuuden tai työtaakan on myös todettu lisäävän eläköitymisaikeita (mm. Elovainio ym. 2005).

Edeltävä katsaus osoittaa, että eläkkeelle siirtymiseen liittyvä tutkimus on sekä kansallisesti että kansainvälisesti monipuolista.
Tässä artikkelissa halutaan korostaa erityisesti ikääntyvien työntekijöiden omia näkemyksiä eläkkeelle siirtymisestä ja työssä jatkamisesta kategoria-analyysiä hyödyntäen. Aikaisempi tutkimus on osoittanut, että joustavan eläkejärjestelmän taloudelliset kannustimet eivät yksinomaan riitä työssä jatkamisen motivointikeinoiksi (Tuominen ym. 2010, Alasoini 2012). Kategoria-analyysillä on mahdollista nostaa esille ihmisten erilaisia arkielämän moraalisia järkeilytapoja (Juhila ym. 2012a ja 2012b), jotka vaikuttavat heidän päätöksiinsä työssä jatkamisesta ja eläkkeelle siirtymisestä.

\section{Aineisto}

Artikkeli pohjautuu ESR-rahoitetussa Toimintakyvyn vaikutus työelämään (TOVA) -hankkeessa vuosina 2013-2014 toteutettuihin neljän yrityksen henkilöstöjen haastatteluihin. Yritykset olivat erikokoisia itäsuomalaisia teollisuus-, pankki- ja kaupan alan yrityksiä. Aineistoon otettiin mukaan ikääntyvien, vähintään 40-vuotiaiden, henkilöiden haastattelut, joiden käytölle tieteellisen artikkelin aineistona oli saatu haastateltavien lupa $(\mathrm{n}=35)$.

Haastattelut toteutettiin (ensimmäinen kirjoittaja) yksilöhaastatteluina puolistrukturoidulla teemahaastattelulla. Teemat käsittelivät haastateltavien käsityksiä omasta työhyvinvoinnistaan ja tulevaisuuden näkymistään eläköitymisen ja jaksamisen osalta. Johtoasemassa olevilta haastatelluilta kysyttiin myös yleisesti työhyvinvoinnista ja eläköitymisestä yrityksessä. Haastattelut kestivät 20 minuutista yhteen tuntiin, ja niistä kertyi litteroitua tekstiä (neljäs kirjoittaja) yhteensä 151 sivua.

Työnantaja määritteli kolmessa yrityksessä hankkeeseen, ja sitä kautta haastatteluun, osallistujat. Yhdessä yrityksessä henkilökunnan jäsenet ilmoittautuivat hankkeeseen itse. Haastatelluista 13 oli työntekijöitä ja 22 toimihenkilöitä, joista kaksi oli ylempiä toimihenkilöitä. Naisia oli 21 ja miehiä 14. Iältään haastatellut olivat 41-59-vuotiaita keski-iän ollessa 51 vuotta.

Eniten (29 \%) aineistossa oli 50-59-vuotiaita toimihenkilönaisia. Aineiston ainoat 
ylemmät toimihenkilöt olivat 50-59-vuotiaita miehiä. Ikäryhmittäin tarkasteltuna aineistosta huomattava osa (71 \%) oli vanhemman ikäryhmän, 50-59-vuotiaiden, naisten ja miesten haastatteluja.

\section{Aineiston analysointi}

Haastatteluaineisto analysoitiin jäsenkategorisoinnin analyysin (MCA) avulla. MCA on diskursiivisiin eli puheen tutkimuksen menetelmiin lukeutuva laadullinen analyysimenetelmä (Juhila 2004). Se pohjaa etnometodologiseen ajatukseen siitä, että ihmiset luokittelevat eli kategorisoivat jatkuvasti arkielämän toiminnassaan asioita ja ihmisiä. Käytetyt kulttuuriset kategoriat ovat kulttuuriin kuuluville jäsenille itsestäänselvyyksiä, joten kategorisointia tehdään olettaen, että vuorovaikutuksessa muut ymmärtävät asiat samalla tavalla. Tämä mahdollistaa arkisen vuorovaikutuksen. (Garfinkel \& Sacks 1986, Juhila ym. 2012a.)

Analyysimenetelmän avulla on mahdollista selvittää, millaisia ominaisuuksia ja toimintoja eli kategoriapiirteitä kategorioihin liitetään (Antaki \&t Widdicombe 1998, Kinni 2011, Jokinen ym. 2012). Kun puhumme esimerkiksi eläkeläisestä, oletamme, että kuulijamme ymmärtää, mitä se tarkoittaa ja millaisia ominaisuuksia ja toimintoja eläkeläisenä olemiseen kuuluu. Eläkeläisen ajatellaan esimerkiksi olevan eläkeikäinen eikä hänen ajatella käyvän palkkatyössä, muutoin hän rikkoo moraalista kulttuurista järjestystä, minkä johdosta voi joutua selontekovelvolliseksi (Juhila 2012). Kategoriat sisältävät siis runsaasti päätelmiä niihin liittyvistä oikeuksista ja velvollisuuksista (Jayyusi 1984, Sacks 1989, Juhila ym. 2012b).

Aineisto luettiin useaan kertaan ja siitä valittiin tarkempaan analyysiin kohdat, joissa haastateltavat puhuivat itsestään eläkkeelle siirtyjinä tai työelämästä pois jääjinä. Nämä aineistokohdat analysoitiin aineistolähtöisesti jäsenkategorisoinnin analyysillä. Aineistosta etsittiin työssä jatkamiseen ja eläkkeelle siirtymiseen liitettyjä piirteitä eli toimintoja, ominaisuuksia, velvollisuuksia ja oikeuksia.
Näiden perusteella nimettiin neljä kategoriaa, joiden jäsenillä on tietynlainen moraalinen asennoituminen työhön, eläkkeelle jäämiseen ja työuran jatkamiseen. Esimerkiksi aineistootteesta "Kunhan tässä nyt pärjää ja pystyy velvoitteensa hoitamaan ja saa ruokansa" voi päätellä, että puhujan moraalisen järjestyksen mukaisesti työssä käymisen tarkoituksena on lähinnä taloudellisen toimeentulon hankkiminen. Nämä piirteet sisältyvät kategoriaan, joka on tässä tutkimuksessa nimetty leiväntienaajan kategoriaksi.

\section{Tulokset}

Aineiston neljä kategoriaa nimettiin seuraavasti: leiväntienaajat, velvollisuudentuntoiset, tekemistä tarvitsevat ja työstä nauttivat. Velvollisuudentuntoisia (13 henkilöä) ja leiväntienaajia (12 henkilöä) oli haastatellussa joukossa eniten. Tekemistä tarvitseviin kategorisoitui kolme ja työstänsä nauttiviin kuusi haastateltavaa. Leiväntienaajissa oli tasaisesti naisia sekä miehiä ja työntekijöitä sekä toimihenkilöitä. Velvollisuudentuntoisissa oli myös tasaisesti työntekijöitä ja toimihenkilöitä, yhdeksän naista ja neljä miestä. Tekemistä tarvitsevat olivat työntekijä- ja toimihenkilönaisia. Työstä nauttivat olivat kaikki toimihenkilöitä, sekä miehiä että naisia.

\section{Leiväntienaajat}

Leiväntienaajat tekevät työtään lähinnä taloudellisen toimeentulon hankkimiseksi. Tähän kategoriaan kuuluva "haluaa ruokaa ja rahaa", joten "tuloja pitää olla työstä". Osa leiväntienaajista ilmaisi työssä käymisen motiivinsa 52-vuotiaan miestyöntekijän tapaan hyvin suorasukaisesti: "No, rahahan se ratkasee. Se on ainut työnteon motiivi mulla."

Työllä on välineellinen merkitys, eikä työn sisältöä tai sen kehittämistä nähdä itselle tärkeänä. Ei haittaa, vaikka työ onkin jo uran mittaan muodostunut rutiininomaiseksi suorittamiseksi. Tärkeämpää on, että työtä ja siitä saatavaa toimeentuloa on, kuten käy ilmi seuraavasta 50-vuotiaan miestyöntekijän haastattelukatkelmasta. 
"Työtehtävät on jo rutiinia, ei ne sillä tavalla anna, että ne nyt vaan suoritetaan nimimerkillä alta pois."

"Kaipaisitko haasteita tai jotain uutta?"

"No ei välttämättä, minä oon ihan tyytyväinen tähän tilanteeseen. Toivottavasti vain talossa riittää töitä jatkossakin."

Koska taloudellisen toimeentulon hankkiminen on oleellista, on tärkeää, että töitä riittää. Leiväntienaajat nostivatkin esille huolensa työn jatkumisesta. Lisäksi, jotta töissä jaksaisi käydä, on oman työkyvyn säilyttävä. Haastateltavat toivat esille iän tuomat vaivat ja lisääntyneen töistä palautumisen tarpeen. Työelämän vaatimusten koetaan kasvaneen. Kuntoutus nähdäänkin tärkeänä, jotta elannon ansaitseminen olisi mahdollista. Seuraavassa katkelmassa 50-vuotias miestyöntekijä pohtii jaksamista:

"Nyt on herätty tähän jaksamiseen. Kaikkien pitäisi päästä jonkinlaiseen räätälöityyn kuntoutukseen, koska meidän halutaan olevan työkykyisiä mahdollisimman pitkään. Sitä ei edistetä vain eläkeikää nostamalla tai vähentämällä mahdollisuutta sapattivuoteen."

Leiväntienaajalle työelämässä jatkaminen eläkeiän jälkeen ei ole vaihtoehto. Häntä "eläkeiän nosto ei kiinnosta” ja hän haluaa eläkeiän saavutettuaan nauttia, "jos siihen asti ollut töissä, niistä eläkepäivistäkin terveenä ja hyvässä kunnossa”.

Leiväntienaajalla on palkkatyön lisäksi toinenkin mahdollisuus hankkia elantonsa: lottovoitto. Seuraava 50-vuotiaan miestyöntekijän kommentti kuvastaa leiväntienaajien suhtautumista työuran jatkamiseen: "Arvaa, jäänkö eläkkeelle heti, jos saisin lottovoiton!”

Päätöksenteko ei kuitenkaan ole yksioikoista, ja osa lottovoitosta haaveilevista epäröikin työelämästä kokonaan luopumista elämän säännöllisyyden ja sosiaalisten tekijöiden takia:
"Jos saisi rahaa, niin varmaan jäisi heti (pois töistä). Ei kokonaan. Säännöllisyys pitää ihmisen kasassa ja terveenä."

Yllä oleva 55-vuotiaan miestoimihenkilön pohdinta kuvaa hyvin, kuinka ihmiset sijoittelevat itseään ja toisiaan eri kategorioihin ja niistä pois (Billig 1996). Puntarointi johtaa harkitsemaan ristiriitaisiakin vaihtoehtoja. Seuraavassa haastattelukatkelmassa lottoamisesta kertonut 45-vuotias naistoimihenkilö miettii vaihtoehtojaan:

"Jäisitkö, jos saisit lottovoiton ensi lauantaina, kokonaan pois töistä?"

"En, jotenkin tuntuu, että tämä on henkireikä. Tosin voisin ruveta neuvottelemaan vuorotteluvapaita tai jotakin lyhennettyä työaikaa tai tämmöstä. Mutta en mä usko, että jäisin pois kokonaan. Sen mitä on näitä lomautuksia ollut, kyllä se on niin välillä orpo olo ollut, kun ei oo työkavereita nähnyt, ne on semmonen toinen perhe."

Leiväntienaajan suhtautumista työhön kuvastaa, että työ nähdään vain yhtenä tekijänä elämän kokonaisuudessa. "Työ on vain osa elämää", kuten eräs 50-vuotias miestyöntekijä totesi. Harrastusten merkitystä elämässä korostetaan. "Paljon harrastuksia, ei aika nyt riitä", totesi eräs haastateltava, ja toinen: "Siis se vapaa-aika on mulle se tärkee". Harrastusten ja vapaa-ajan tärkeyden korostuminen on ymmärrettävää, jos työllä ei ole merkitystä elämän sisältönä.

Leiväntienaajat kertoivat käyvänsä töissä ansaitakseen elantonsa, eikä työ rakennu heille sisällöllisesti merkitykselliseksi. Huoli työkyvyn säilymisestä ja jaksamisesta eläkeikään saakka liittyy huoleen taloudellisesta toimeentulosta. Kategoriaan liittyvän moraalisen järkeilyn mukaan työ ei saa olla liian tärkeällä sijalla ihmisen elämässä. Töiden jatkamista varsinaisen vanhuuseläkeiän savuttamisen jälkeen ei siten nähdä tavoiteltavana vaihtoehtona. Lottovoitto mahdollistaisi työelämästä pois jäämisen jo ennen eläkeikää. 
Tästä moraalisesta järjestyksestä poikkeamista puolustetaan selonteoilla siitä, kuinka työ tuo elämään säännöllisyyttä ja työyhteisö tarjoaa sosiaalista vuorovaikutusta ja ryhmän jäsenyyttä.

\section{Velvollisuudentuntoiset}

Velvollisuudentuntoisen kuuluu mielestään käydä töissä siihen asti, kuin on säädetty. Näin toimiminen nähdään luonnollisesti olemassa olevana elämän tosiasiana - niin luonnollisena, että sitä ei edes pohdita tai kyseenalaisteta (Juhila 2012a). Seuraavissa aineisto-otteissa on 50- ja 51-vuotiaiden työntekijänaisten ajatuksia työelämässä jatkamisesta vanhuuseläkeikään saakka.

"En minä ole ajatellut, että haluanko minä olla vai enkö minä halua olla. Eikös sitä yleensä olla? Olen pitänyt itsestään selvyytenä, että sitä ollaan.”

"Koska on se työvelvollisuus, kyllä mä haluaisin terveenä olla, että sais tehdä työvuodet täyteen."

Eläkejärjestelmä kulttuurisena moraalisena instituutiona rakentaa voimakkaasti velvollisuudentuntoisten suorittajien ajatusta siitä, että on oikeutettua siirtyä pois työelämästä vasta eläkeikäisenä. 63 vuoden eläkeikäraja toistui velvollisuudentuntoisten puheessa. Vanhuuseläkeikä on selkeä rajapyykki, joka oikeuttaa ihmisen siirtymisen työssä käyvän kategoriasta eläkkeellä olevan kategoriaan.

Velvollisuuden täyttäjä odottaa, että palkkiona uurastuksesta hän saa nauttia eläkkeestä hyväkuntoisena. 50-vuotias naistyöntekijä pohti:

"Sitten se on sallittua se semmonen, minun päässä sallittua, vielä ei ole. Tämän ikäisenä ei ole vielä sallittua, että on poissa töistä. Mutta 63-vuotiaana, vähäkö on mukava jäädä eläkkeelle. Hyvinvoivana ehkä matkustella, olla." vollisuudentuntoistakaan. Oikeutta eläkkeellä oloon perustellaan 57-vuotiaan miestoimihenkilön tapaan velvollisuuden täyttämistä pitkällä työuralla:

"Mä oon alottanu 16-vuotiaana työn-
teon, mulla on yli 40 vuotta työhisto-
riaa takana. Sitä oon miettinytkin ai-
na, että kun pääministeri puhuu, että
työurat pitäs pidentää, niin että jos mä
oon siihen 63 , niin mulle tulee työhis-
toriaa lähes 46 vuotta. Kyllä siinä luu-
lis jo yhelle miehelle olevan."

Ennen varsinaista vanhuuseläkeikää työelämästä pois jääminen rikkoo moraalista järjestystä ja vaatii selontekoja. Perheeseen liittyvät hoivavelvollisuudet riittävät ohittamaan työntekovelvollisuuden. Hoivavelvoitteesta puhuneet haastateltavat olivat seuraavan katkelman 50-vuotiaan toimihenkilön tapaan kaikki naisia:

"Jos mun mies sairastus, ja sit haluis viettää yhteistä aikaa. Puhumattakaan jos lapsille tai lapsenlapsille jotain sattus. Perhe on tosi tärkee, ja jos jotain tämmöstä perhesyytä olis, niin sillon mä kyllä työstä irrottaudun.”

Lisäksi "liian aikaiselle" työelämästä vetäytymiselle tarjottiin perusteluna oikeutta nauttia ansaitusta vapaudesta terveenä työuran jälkeen. Velvollisuutta pysyä työelämässä ja oikeutta nauttia ansaitusta vapaasta puntaroitiin 58-vuotiaan naistoimihenkilön tapaan:

"Voisiko kuusikymppisenä olla sopiva ikä jäähä, kun sitä ajattelee, kun on joitakin tapauksia tuttavapiirissä, että sitten kun eläkeaika koittaa, niin sittenpä siitä ei kerkee nauttia, tai jo ennen sitä terveys pettää taikka jopa kuolema tulee? Niin sit aina miettii sitä, että entäs jos jäiskin jo aiemmin, että kerkeis nauttia."

Työuran jatkaminen ei houkuttele vel- 
Velvollisuudentuntoisten eläkeratkaisuihin vaikuttaa lähinnä eläkeikäraja. Heidän työssä jatkamiseensa vaikuttaa tämän perusteella eniten se, mihin eläkeikäraja yhteiskunnassa asetetaan. Tämä moraalinen järjestys kuitenkin rakoilee, ja velvollisuudentuntoinenkin tulkitsee muuttuvia elämäntilanteitaan ja arvojärjestystään (Juhila ym. 2012a). Velvollisuudentuntoiset tuovat voimakkaasti esille terveyden merkitystä sekä ennen että jälkeen eläkeiän.

\section{Tekemistä tarvitsevat}

Tekemistä tarvitsevien puheessa korostui työssä käymisen merkitys elämään rutiineja ja mielekkyyttä rakentavana sekä sosiaalisia suhteita ylläpitävänä tekijänä. Tekemistä tarvitsevat kertoivat, että ovat lapsesta saakka tottuneet siihen, että aina on jotain tehtävää, kuten 46-vuotias naistoimihenkilö kuvailee:

”Jotainhan sitä pitää tehdä, että saa päivän kulumaan sillä lailla sujuvasti ja hyvin, ja on mielekästä tekemistä. Pienestä pitäen tottunut tekemään töitä. Kyllä mulla varmaan tekemistä ois kotonakin, mutta se vois käydä ykstoikkoseks. Kun sä oot töissä ja jossain yhteisössä mukana, sulla on siellä erilaisia ystävyyssuhteita ja muita. Se tuo niin erilaisen sisällön elämään, ja toisaalta pysyy sitten päivässä rytmikin.”

Tekemistä tarvitsevat eivät puhuneet aineistossa työn sisällöstä. Tärkeämpää on työssä käyminen arjen jäsentäjänä ja kuuluminen työyhteisöön. Myös hoiva on heille mielekäs vaihtoehto, se on tässäkin kategoriassa naisten asia. Seuraavan katkelman 57-vuotias naistoimihenkilö odotti lastenlapsia hoidettavaksi ja kokee vanhempien hoitamisen velvollisuudeksi.

"Oon aina sanonu, että jos minulle tulee lastenlapsia, niin sitten vois olla semmonen vaihtoehto, että jos siellä tarvii hoitajaa, et mikä ettei sitten vaikka osa-aikaistakin eläkettä tai jotain. Vanha isäni asuu [X:ssa], käyn siellä joka toinen viikonloppu, hoidan hänen asioitaan. Semmonen tehtävä on.”

Tekemistä tarvitsevat haluavat olla töissä eläkeikään, eikä tekemisen tarve johda työuran jatkamiseen. Jaksaminen ja terveys nostettiin esille tässäkin kategoriassa. Seuraavan haastattelukatkelman 50-vuotias naistyöntekijä pohti erilaisia mahdollisuuksia:

"Minä oon aatellu, että aina oon ollut
niin pienipalkkasessa työssä, että elä-
ke ei ois iso, jos joutuis aikasempaan
jäämään. Että kyllä rahallisestikin oon
ihan siihen loppuun asti."
"Mikä olisi tarpeeksi hyvä tai riittävä
syy jäädä ennen sitä?"
"Sairaus. Jos et jaksa tai et pysty teke-
mään. Tai sitten joku läheinen jos sai-
rastuu ja se tarvii, niin se on taas sitten
eri asia. Mutta en muuten."

Työ ja työyhteisö ovat tekemistä tarvitseville yksi vaihtoehto mielekkäiden tekemisten joukossa. Joutilaisuutta ei nähdä hyvänä asiana. Työssä pysymisen velvollisuus sinällään tai palkkatulojen tarve ei korostunut heidän puheessaan niin voimakkaasti kuin velvollisuudentuntoisilla tai leiväntienaajilla. Mikäli tarjolla olisi muuta mielekästä tekemistä, se voisi korvata palkkatyön. Läheisten hoitaminen näyttäytyy sellaisena palkkatyön vaihtoehtona. Eläkeiän jälkeen hekään eivät ole valmiita jatkamaan työssä.

\section{Työstä nauttivat}

Työstä nauttivalle työllä sinällään on merkitystä. Ammattitaito ja uralla kehittyminen rakentavat työn merkityksellisyyttä.

"Kun aamulla herätään ja töihin lähetään, niin sen pitää olla mielekästä ja semmonen tuntu, että menee mielellään työpaikalle. Se onni ollut, kun pitkä ura, että työtehtävät ovat vaihtuneet. Sitä kautta en ole millonkaan kokenu semmosta uupumisen tunnetta. Päinvastoin, hyvin on mielenkiintoisia teh- 
täviä ollut. Minä tykkään työstä, minä nautin. Ja sitten, kun päivät ei oo sitä konttorityöaikaa, niin sinä jaksat sen kautta, kun sinä koet sen työn mielekkäänä. Kaikki muu tulee sitten siinä mukana. Kovaa ammattitaitoa vaatii.”

"Oikeestaan aina oon ollu hirveen tyytyväinen työhöni. Että en tiedä sitten, jos etenemismahdollisuuksia ei ois ollu. Se on minusta itsestäni kiinni, että oon lähteny niihin haasteisiin."

Yllä olevien otteiden ylempi toimihenkilömies ja toimihenkilönainen ovat ylpeitä ammattitaidostaan, aikaansaannoksistaan ja uskaltautumisestaan haasteisiin. Työssä on saatu aikaan ja edetty. Taloudellisista tekijöistä ei puhuta työn ensisijaisena motiivina. Toimihenkilömies totesi: "Ei se raha oo ainut autuus tässä maailmassa, ei missään muotoo". Työ sisältöineen tuntuu luovan heille hyvinvointia ja lisäävän jaksamista.

Työelämä on haasteellista, mutta koska se on niin mielekästä ja motivoivaa, siitä ei silti haluta luopua. Työstänsä nauttiva henkilö voikin olla hyvin vastuullisessa ja paineisessa asemassa, mutta motivaatio voittaa paineet: ”On tekijöitä, jotka motivoi. Kun on synkkää, ajattelee, että pääsis [eläkkeelle]. [Työ on] stressaavaa, superstressaavaa."

Työstä nauttiva haluaa tehdä mielekästä työtä, jolla on merkitystä - ja jatkaa tällaista työtä vanhuuseläkeikärajan ylikin. Hän on ylpeä ammattitaidostaan ja uskoo, että se voi kehittyä vielä ikääntyvänäkin niin, että siitä on hyötyä työnantajalle, kuten seuraavat naistoimihenkilöt kuvasivat:

"Mä tykkään työstäni ja oon jopa aatellut, että jos terveys on yhtä hyvä kuin nyt ja muuta, voin jatkaakin ihan sillä tavalla kun itse haluan, jos se on mahdollista. Asiakkaiden kanssa työskenteleminen on niin antoisaa, ja nytkin on jo hyvä ammattitaito, niin luulen, että siitä on paljonkin hyötyä."
"Pystyn, pystyn sinällään [kuvittelemaan, että jatkaa töissä 68-vuotiaaksi]. Et jos vain kokee, että sillä, mitä tekee on merkitystä. Silleen en halua missään nimessä jäädä ikään kuin vaan roikkumaan. Että mä haluun olla töissä, mutta silleen mitään merkitystä työnantajan kannalta, niin en mä sellasta haluu."

Työstä nauttivat pystyvät vaikuttamaan työhönsä ja arvostavat sitä mahdollisuutta. He puhuivat itseään oman elämänsä vaikuttajiksi. Terveyteensä he eivät kuitenkaan katsoneet voivansa täysin vaikuttaa. Ylempi miestoimihenkilö mietti: "Pahin vaihtoehto, että terveys ei kestä."

Työstä nauttivan moraaliseen kulttuuriseen järjestykseen kuuluu, että työssä kehitytään ja jaksetaan yrittää raskainakin aikoina. Työhön suhtaudutaan antaumuksellisesti, omaa ammattitaitoa arvostetaan ja kehitetään, myös ikäännyttäessä. Asioihin voidaan vaikuttaa itse. Työstänsä nauttijat ovat tässä aineistossa toimihenkilöitä tai ylempiä toimihenkilöitä. Heille varsinainen eläkeikä ei ole itsestään selvä rajapyykki eläkkeelle siirtymiseen. Mielekäs ja merkityksellinen työ, johon voi itse vaikuttaa, kokemus, että on hyödyksi työnantajalle, ja mahdollisuudet kehittyä ja edetä työssä edistävät tämän ryhmän pysymistä työelämässä ja jatkamista eläkeiän jälkeen. He ovat aineiston ainoa ryhmä, joka ilmaisi halua jatkaa työelämässä varsinaisen eläkeiän jälkeen - mikäli terveyttä riittää.

\section{Pohdinta}

Tutkimuksen tavoitteena oli analysoida, millaisina tutkimuksen ikääntyvät työntekijät näkevät itsensä eläkkeelle jääjinä tai työssä jatkajina. Lisäksi tavoitteena oli tarkastella, miten työkykyyn, terveyteen tai kuntoutukseen liittyvät teemat tulevat esille haastateltavien puheissa. Haastatellut yli 40-vuotiaat tulivat neljästä eri yrityksestä yhden maakunnan alueelta. He olivat sosioekonomiselta taustaltaan lähinnä työntekijöitä tai toimihenkilöitä - joukossa oli vain kaksi ylempää toimihen- 
kilöä. Haastattelut osoittivat, että he jäsentävät eri tavoilla suhdettaan työhön, eläköitymiseen ja jäljellä olevaan työuraan. Analyysissä haastateltavat sijoittuivat tämän suhteen neljään kategoriaan eli leiväntienaajiin, velvollisuudentuntoisiin, tekemistä tarvitseviin ja työstä nauttiviin. Ainoastaan työstä nauttivat toimihenkilöt olivat kiinnostuneita jatkamaan työelämässä eläkeiän jälkeen. Puheissa tuotiin esille terveyden, työssä jaksamisen ja työyhteisön merkitys jatkamiselle.

Saatuja tutkimustuloksia on mahdollista suhteuttaa aikaisempaan tutkimusnäyttöön työelämästä työntävistä ja eläkkeelle vetävistä tekijöistä tai Barnes-Farrellia (2003) soveltaen työelämään vetävistä tekijöistä. Leiväntienaajien osalta kytkös aikaisempaan tutkimukseen on selkeä. Heidän osaltaan työssä jatkaminen on keskeisesti yhteydessä taloudelliseen tilanteeseen (ks. Beehr 1986, Gaillard \& Desmette 2008, Dufva 2012, Perkiö-Mäkelä ym. 2012). Ansiotulojen välttämättömyys pitää leiväntienaajan työelämässä, muu tapa saada elantoa, esimerkiksi lottovoitto, vetäisi eläkkeelle. Työyhteisön toimivuus ja ilmapiiri voivat vahvistaa tähän ryhmään kuuluvien henkilöiden työssä jaksamista eläkeikään saakka (ks. Manka \&t Nuutinen 2013), samoin kuin työkyvyn ylläpitäminen ja työhyvinvoinnin kehittäminen (ks. Salokangas ym. 2005, Karisalmi ym. 2008, Väänänen-Tomppo 2010, de Wind ym. 2013). Tässä ryhmässä tarvitaan kuntoutusta työkyvyn ylläpitoon ja työn räätälöintiin taloudellisen toimeentulon varmistamiseksi.

Velvollisuudentuntoisuus ei ole korostunut aikaisemmassa tutkimuksessa työelämään vetävänä tekijänä. Tässä tutkimuksessa kolmasosa haastateltavista korosti selkeästi velvollisuuttaan jatkaa asetettuun normiin eli eläkeikään asti. Tämän ryhmän osalta todennäköisesti myös jatkossa virallinen eläkeikä määrittää eläkkeelle siirtymistä. Velvollisuudentuntoiset olivat tässä pienessä haastattelujoukossa lähinnä 50-59-vuotiaita naisia. Tutkimuksen muidenkin tulosten tapaan tämäkin tulos on aineistosta ja tutkimusmenetelmästä johtuen kontekstisidonnainen, joten sen yleisyyttä olisi kiinnostavaa tarkastella laajalla pitkittäistutkimuksella. Tässäkin ryhmässä terveyttä edistävä ja työky- kyä ylläpitävä toiminta sekä niiden lisäksi joustava työaika auttaisivat pysymään työelämässä ainakin vanhuuseläkeikään saakka.

Haastatelluista edellä käsiteltyjä ryhmiä pienempi osa jäsensi itsensä tekemistä tarvitseviin tai työstä nauttiviin. Näissä molemmissa ryhmissä tekemisellä on keskeinen rooli yksilön elämässä. Tekemistä tarvitsevien ryhmässä on mahdollista, että tekeminen suuntautuu muuhunkin kuin työhön. Aiemmissa tutkimuksissa on todettu, että moraalinen velvoite hoivaan on edelleen varsin vahva, ja suurimman osuuden kaikesta hoivasta tekevät läheiset ja omaiset palkatta (Anttonen ym. 2009, Anttonen \&t Zechner 2009). Hoivavelvollisuus voikin vetää tekemistä tarvitsevan lisäksi velvollisuudentuntoisen pois työelämästä. Joustavat työelämäratkaisut mahdollistaisivat työelämässä jatkamisen. Työstä nauttiville työn sisältöön, johtamiseen ja kehittämismahdollisuuksiin liittyvillä panostuksilla on todennäköisesti suurempi merkitys työssä jatkamiselle kuin tutkimuksen muille kategorioille (ks. Manka \& Nuutinen 2013). Mielekkääksi koettuun työhön voi liittyä stressiä aiheuttavia tekijöitä, joihin tulisi pystyä vaikuttamaan varhaisessa vaiheessa.

Yllättävä tulonlähde, kuten lottovoitto, rakentaa tässä tutkimuksessa haavetta toimeentulosta ja valinnanmahdollisuuksista. Lottovoitto näyttäytyy voimakkaana työelämästä pois työntävänä tekijänä. Toisaalta puhe lottovoitosta nostaa näkyville ristiriitaisuutta ja pohdintaa, jota työelämästä vetäytymiseen yksilötason päätöksenteossa liittyy. Vaikka saisin lottovoiton eikä työllä ole minulle sisällöllistä merkitystä, haluaisinko kuitenkaan jäädä pois työstä ja luopua sen tuomasta rutiinista ja työyhteisöstä? Monitahoisuus ilmeni analyysitasollakin, sillä saman haastateltavan puheesta oli löydettävissä piirteitä eri kategorioista. Kategoriat eivät ole valmiiksi annettuja vaan puheessa rakentuneita ja tutkijoiden nimeämiä sen perusteella, mitkä toiminnot ja merkitykset nousivat voimakkaimmin esiin haastatteluaineistosta (Juhila ym. 2012b).

Kokonaisuudessaan tämä tutkimus osoittaa aikaisempien tutkimusten tapaan, ettei 
työssä jatkamista ja eläkkeelle siirtymistä voi arvioida yhdestä näkökulmasta (ks. Perhoniemi 2016). Työelämässä jatkamiseen liittyvät kannustimet ovat erilaisia työhön ja eläköitymiseen eri tavoilla suhtautuvilla. Täten myös kannustejärjestelmiä ja -ohjelmia sekä työelämässä jatkamiseen tähtäävää kuntoutusta pitäisi pystyä henkilökohtaistamaan työntekijöiden yksilöllisten tarpeiden mukaisesti, huomioimaan varhainen mukaantulo ja työelämäintegraatio (ks. Aalto ym. 2015, Vainiemi 2015) sekä monialaisten toimijoiden vahva kuntoutuskumppanuus (ks. Hinkka ym. 2015). Työurien pidentämisen kannalta korostuu työhyvinvointijohtaminen (Karttunen ym. 2017). Tutkimustuloksina saatuja kategorisointeja on mahdollista käyttää yksilöiden henkilökohtaistettua kuntoutusta suunniteltaessa. Tällöin syntyisi myös mielekkäitä tutkimuskohteita kannustejärjestelmien ja -ohjelmien sekä kuntoutuksen vaikuttavuudesta eri kategoriaryhmissä.

Tulosten merkitys: Työelämässä jatkamiseen liittyvät kannustimet ovat erilaisia työhön ja eläköitymiseen eri tavoilla suhtautuvilla. Siksi kannustejärjestelmiä ja kuntoutusta työelämässä jatkamiseen tulisi räätälöidä ennakoivasti sekä yksilöiden erilaisten tarpeiden mukaisesti. Tämä haastaa erityisesti työhyvinvoinnin johtamista.

\section{Tiivistelmä}

Ikääntyvien työurien odotetaan pitenevän niin Suomessa kuin kansainvälisesti. Aikaisempi tutkimus on tarkastellut monipuolisesti työurien pitenemiseen yhteydessä olevia yksilö- ja organisaatiotason tekijöitä. Tässä artikkelissa kuvaamme jäsenkategorisoinnin analyysin keinoin, millaisina ikääntyvät työntekijät näkevät itsensä eläkkeelle jääjinä tai työssä jatkajina. Lisäksi tarkastelemme, näkyvätkö työkykyyn, terveyteen tai kuntoutukseen liittyvät teemat kategorisoinneissa. Tavoitteena on ymmärtää työelämässä jatkamiseen tai eläkkeelle siirtymiseen liittyviä tekijöitä yksilöiden näkökulmista.

Aineistona oli 35 yli 40-vuotiaan työntekijän tai toimihenkilön haastattelua neljästä eri yrityksestä. Aineisto analysoitiin aineistolähtöisesti jäsenkategorisoinnin analyysillä. Aineistosta löytyi neljä tapaa järkeillä suhdetta työhön ja eläköitymiseen: leiväntienaajien, velvollisuudentuntoisten, tekemistä tarvitsevien ja työstä nauttivien. Nämä kategoriat sisältävät myös käsityksiä työkyvyn ja kuntoutuksen merkityksestä.

Ainoastaan työstä nauttivat ovat kiinnostuneita jatkamaan työuraa eläkeiän jälkeen. Heille työn sisällöllä on suuri merkitys. Leiväntienaajille työllä on välineellinen merkitys toimeentulon lähteenä - jonka myös lottovoitto toisi. Velvollisuudentuntoisille työelämässä pysyminen asetettuun eläkeikärajaan saakka näyttäytyy itsestäänselvyytenä. Tekemistä tarvitsevilla taas esimerkiksi omaisten hoivaaminen voisi korvata työelämän.

Eri kategorioissa tehdään päätöksiä työssä jatkamisesta erilaisin perustein. Kaikissa kategorioissa tuotiin kuitenkin esille terveyden, työssä jaksamisen ja työkyvyn merkitys. Tutkimuksessa on tärkeä keskittyä arvioimaan erilaisten kannusteiden merkitystä työssä jatkamiselle erilaisissa ryhmissä. Jaksamisen tukemiseen sekä työkyvyn ylläpitoon ja parantamiseen tarvitaan henkilökohtaistettuja ratkaisuja.

Avainsanat: työssä jatkaminen, eläkkeelle siirtyminen, ammatillinen kuntoutus, jäsenkategorisoinnin analyysi 


\section{Abstract}

Ageing employees reasoning work and retirement

Working careers of ageing employees are expected to extend in Finland, as well as internationally. Previous research has revealed various factors on individual and organisational level that have an impact on longer working careers. This article describes how ageing employees see themselves as retiring or continuing at work by the means of category analysis. It also explores if the themes of work ability, health or rehabilitation are found in categorisations. The aim of the study is to understand factors related to retiring or continuing work from the individual point of view.

The data consists of 35 interviews of employees 40 years of age or above in four enterprises. Data were analysed data-driven by membership category analysis. Four different ways to reason one's attitude to work and retirement were found: those of breadwinners, dutiful ones, those who need activities and those who enjoy working. These categories also include perceptions on the significance of an ability to work and rehabilitation.

Only those who enjoy working are interested to continue in working life beyond their retirement age. The content and meaning of work is very important to them. To a breadwinner work is instrumental in earning one's living - which would also be fulfilled by winning in lottery. Dutiful ones think it is self-evident to stay in working life until the institutional retirement age but not beyond. Those who need activities could compensate paid work for caring.

People in different categories make decisions on continuing in working life on different grounds. However, the significance of health, coping at work and ability to work were mentioned as decisive factors in all categories.

It is suggested that it is important to focus on evaluating the meaning of incentives for continuing work in different groups. In addition, personalised solutions are needed in supporting workers to cope at work and also in maintaining and improving their working ability.

Relevance of the results: Categories include different moral views on continuing working careers and retirement, and it is possible to use categorisations in planning personalised rehabilitation for individual emloyees. This creates challenges for welfare management.

Keywords: continuing at work, retirement, vocational rehabilitation, membership category analysis

Riitta-Liisa Kinni, YTT, yliopistonlehtori, Yhteiskuntatieteiden laitos, Itä-Suomen yliopisto

Helena Taskinen, FT, yliopistotutkija, Sosiaali- ja terveysjohtamisen laitos, Itä-Suomen yliopisto

Elsa Paronen, FT, projektipäällikkö, Sosiaali- ja terveysjohtamisen laitos, Itä-Suomen yliopisto (3.10.2016 alkaen muutosjohtaja, Pohjois-Savon Liitto)

Katja Pesonen, KTM, projektitutkija, Sosiaali- ja terveysjohtamisen laitos, Itä-Suomen yliopisto (1.8.2015 alkaen taloussihteeri, Itä-Suomen yliopiston talouspalvelut)

Sari Rissanen, YTT, TtL, dekaani, Yhteiskuntatieteiden ja kauppatieteiden tiedekunta, Itä-Suomen yliopisto

\section{Lähteet}

Aalto A-M, Heponiemi T, Elovainio M, Vehko T, Syrjä V (2015) Työssä, hyvinvoinnissa ja työkyvyssä tapahtuneet muutokset työhönkuntoutujilla. Kuntoutus 37, 3, 11-27.

Aalto A-M, Hurri H, Järvikoski A, Järvisalo J, Karjalainen V, Paatero H, Pohjolainen T, Rissanen P (toim.) (2002) Kannattaako kuntoutus? Asiantuntijakatsaus eräiden kuntoutusmuotojen kannattavuudesta. STAKES, Raportteja 267, Helsinki.

Alasoini T (2012) Eväitä työssä jatkamiseen: kuinka 
suomalaisten työurat saadaan jatkumaan pidempään? Työpoliittinen Aikakauskirja 1:21-32.

Ammatillinen KIILA-kuntoutus työssäoleville. KELA. http://www.kela.fi/kiila-kuntoutus Luettu 6.4.2017.

Antaki C, Widdicombe S (1998) Identity as an Achievement and as a Tool. Teoksessa C Antaki, S Widdicombe (toim.) Identities in Talk. Sage, London.

Anttonen A, Valokivi H, Zechner M (2009) Johdanto. Teoksessa A Anttonen, H Valokiva, M Zechner (toim.) Hoiva. Tutkimus, politiikka ja arki. Vastapaino, Tampere.

Anttonen A, Zechner M (2009) Tutkimuksen lähestymistapoja hoivaan. Teoksessa A Anttonen, H Valokivi, M Zechner (toim.) Hoiva. Tutkimus, politiikka ja arki. Vastapaino, Tampere.

Barnes-Farrell JL (2003) Beyond Health and Wealth Attitudinal and Other Influences on Retirement Decision-Making. In GA Adams, TA Beehr (toim.) Retirement: Reasons, Processes, and Results. Springer Publishing Company, New York.

Beehr TA (1986) The process of retirement: A review and recommendations for future investigation. Personnel Psychology 39, 1, 31-55.

Billig M (1996) Arguing and thinking. A rhetorical approach to social psychology. Cambridge University Press, Cambridge.

De Wind A, Geuskens GA, Reeuwijk KG, Westerman MJ, Ybema JF, Burdorf A, Bongers P, Van der Beek AJ (2013) Pathways through which health influence early retirement: a qualitative study. BMC Publ Health 13, 292, 1-9. http://www.biomedcentral. com/content/pdf/1471-2458-13-292.pdf Luettu 24.6.2015.

Dufva H (2012) Eläkkeelle siirtymisen kynnyksellä Eläkkeellesiirtymisilmiön monitasoinen tarkastelu. Väitöskirja, Itä-Suomen yliopisto, Yhteiskuntatieteiden ja kauppatieteiden tiedekunta, Sosiaali- ja terveysjohtamisen laitos, Kuopio.

Elovainio M, Forma P, Kivimaki M, Sinervo T, Sutinen R, Laine M (2005) Job demands and job control as correlates of early retirement thoughts in Finnish social and health care employees. Work Stress 19, 84-92.

Gaillard M, Desmette D (2008) Intergroup predictors of older workers' attitudes towards work and early exit. European Journal of Work and Organizational Psychology 17, 4, 450-481.

Garfinkel H, Sacks H (1986) On formal structures of practical actions. Teoksessa G Harold (toim.) Ethnomethodological studies of work. Routledge Et Kegan Paul, London and New York.

Gould R, Koskinen S, Sainio P, Blomgren J, Kivekäs J,
Ilmarinen J, Husman P, Seitsamo J (2012) Työkyky. Teoksessa S Koskinen, A Lundqvist, N Ristiluoma (toim.) Terveys, toimintakyky ja hyvinvointi Suomessa 2011. Raportti 68/2012. Terveyden ja hyvinvoinnin laitos, Helsinki.

Heponiemi T, Kouvonen A, Vänskä J, Halila H, Sinervo T, Kivimäki M, Elovainio M (2008) Health, psychosocial factors and retirement intentions among Finnish physicians. Occupational Medicine 58, 406-412.

Hinkka K, Aalto L, Toikka T (2015) Uudenlaiseen Kelan työhönkuntoutukseen. Viiden kuntoutusmallin arvioinnin tuloksia. Sosiaali- ja terveysturvan tutkimuksia 134, Kela, Helsinki.

Huuhtanen P, Tuomi K (2006) Työ ja työkyky vakavien eläkeajatusten ennustajina: seurantatutkimus kunta-alalla 1981-92 sekä eläke ajatusten toteutuminen 1997. Työ ja ihminen 20, 1, 22-41. http://www.ttl.fi/fi/tyo_ja_ihminen/Documents/ Tyojaihminen_1_2006.pdf Luettu 15.5.2017.

Jayyusi L (1984) Categorization and the Moral Order. Routledge \&t Kegan Paul, Boston, London, Melbourne and Henley.

Jokinen A, Juhila K, Suoninen E (2012) Esipuhe ja lukuohje. Teoksessa A Jokinen, K Juhila, E Suoninen (toim.) Kategoriat, kulttuuri ja moraali. Vastapaino, Tampere.

Juhila K (2004) Sosiaalityön vuorovaikutuksen tutkimus. Historiaa ja nykysuuntauksia. Janus 12, 2, 155-183.

Juhila K (2012) Ongelmat, niiden selittäminen ja kategoriat. Teoksessa A Jokinen, K Juhila, E Suoninen (toim.) Kategoriat, kulttuuri \& moraali. Vastapaino, Tampere.

Juhila K, Jokinen A, Suoninen E (2012a) Kategoriaanalyysin juuret. Teoksessa A Jokinen, K Juhila, E Suoninen: Kategoriat, kulttuuri \&t moraali. Vastapaino, Tampere.

Juhila K, Jokinen A, Suoninen E (2012b) Kategoriaanalyysin teesit. Teoksessa A Jokinen, K Juhila, E Suoninen: Kategoriat, kulttuuri \&t moraali. Vastapaino, Tampere.

Järnefelt N (2010) Education and Longer Working Lives. A longitudinal study on education differences in the late exit from working life of older employees in Finland. Studies 1. Finnish Centre for Pensions, Helsinki.

Järnefelt N, Perhoniemi R, Saari P (2014) Työolot ja eläkeajatukset 2013. Eläketurvakeskus, Eläketurvakeskuksen raportteja 08, Helsinki.

Kannisto J (2016) Eläkkeellesiirtymisikä Suomen työeläkejärjestelmässä. Eläketurvakeskus, Eläketurvakeskuksen tilastoraportteja 03, Helsinki. 
Karisalmi S, Tuominen E, Kaliva, K (2008) Eläkeaikomukset ja eläkkeellesiirtyminen - Seurantatutkimus Joustava eläkeikä -tutkimuksen aineistosta. Eläketurvakeskuksen tutkimuksia 2. Eläketurvakeskus, Helsinki.

Karttunen A, Sipponen J, Tukiainen T, Taskinen H, Hakulinen H, Kesti P, Laaksonen M, Lammintakanen J (2017) Työhyvinvoinnin johtaminen. Käytäntöjä ja kokemuksia ELVO-hankkeesta. Publications of the University of Eastern Finland, General Series No 20, University of Eastern Finland, Kuopio. http://epublications. uef.fi/pub/urn_isbn_978-952-61-2446-9/urn_ isbn_978-952-61-2446-9.pdf Luettu 26.9.2017.

Kauppinen T, Mattila-Holappa P, Perkiö-Mäkelä M, Saalo A, Toikkanen J, Tuomivaara S, Uuksulainen S, Viluksela M, Virtanen S (toim.) (2013) Työ ja terveys Suomessa 2012. Seurantatietoa työoloista ja työhyvinvoinnista. Työterveyslaitos, Helsinki.

Kinni R-L (2011) Jäsenkategorisoinnin analyysi palvelutarpeen määrittelyssä. Janus 19, 1, 20-35.

Kuoppala J, Lamminpää A (2008) Rehabilitation and work ability: A systematic literature review. Journal of Rehabilitation Medicine 40, 796-804.

Laine M, Laakso S, Wickström G (2010) Yli 50-vuotiaiden valmius jatkaa sosiaali- ja terveydenhuollon työssä. Työelämän tutkimus $8,1,3-12$.

Lind EA, Tyler T (1988) The social psychology of procedural justice. Plenum Press, New York.

Manka M-L, Nuutinen S (2013) Sosiaalinen ja psykologinen pääoma työuran jatkamisen edistäjinä. Työpoliittinen Aikakauskirja 1, 29-41.

Nikander, P (2002) Age in Action. Membership Work and Stages of Life Categories in Talk. Suomalaisen Tiedeakatemian toimituksia, Humaniora 321. Helsinki: Academia Scientiarum Fennica.

Pasternack I, Autti-Rämö I, Hinkka K, Pappila J (2015) Miten tunnistaa varhaiskuntoutuksen tarve työelämässä? Kirjallisuuskatsaus työkyvyn heikkenemisen ennusmerkeistä ja varhaisen tunnistamisen työkaluista. Sosiaali- ja terveysturvan selosteita 19, Kelan tutkimusosasto, Helsinki.

Pekka T (2010) Keitä ne on ne työssä jatkajat? - Tutkimus eläkeaikeista ja työssä jatkamisen tukemisesta kunta-alalla. Teoksessa P Forma, R Kaartinen, T Pekka, J Väänänen (toim.) Jaksaako jatkaa? Artikkeleita kuntatyön muutoksesta ja työssä jatkamisen tukemisesta kunta-alalla. Kuntatyö 2010 -hanke, Kuntien eläkevakuutus, Kunnallinen työmarkkinalaitos, Suomen Kuntaliitto.

Pensola T, Gould R, Autti-Rämö I, Kivekäs J, Luoma M-L (2012) Koettu kuntoutuksen tarve. Teoksessa S Koskinen, A Lundqvist, N Ristiluoma (toim.) Terveys, toimintakyky ja hyvinvointi Suomessa
2011. Raportti 68. Terveyden ja hyvinvoinnin laitos, Helsinki.

Perhoniemi R (2016) Työn imun ja henkisen kuormittumisen yhteys eläkeaikeisiin työkyvyn mukaan. Teoksessa N Järnefelt (toim.) Työolot ja työurat - tutkimuksia työurien vakaudesta ja eläkkeelle siirtymisestä. Eläketurvakeskuksen Tutkimuksia 2016, Helsinki.

Perkiö-Mäkelä M, Kauppinen T, Hirvonen M (2012) Suomalaisten työssä jatkamisen harkitseminen ja eläkeajatukset. Teoksessa M Perkiö-Mäkelä, T Kauppinen (toim.) Työ, terveys ja työssä jatkamisajatukset. Työterveyslaitos, Työ ja ihminen, Tutkimusraportti 41, Helsinki.

Reeuwijk KG, de Wind A, Westerman MJ, Ybema JF, van der Beek A, Geuskens G (2013) All those things together made me retire: qualitative study on early retirement among Dutch employees. BMC Public Health, 13 (516), 1-11. http://www.biomedcentral.com/content/pdf/1471-2458-13-516.pdf Luettu 15.5.2016.

Sacks H (1989) Lecture Six. The M.I.R. Membership Categorization Device. Human Studies 12, 3/4, 271-281.

Salokangas T, Vuori J, Huuhtanen P (2005) Kohti hallittua työuraa ja eläkeprosessia - Katsaus eläkkeelle siirtymiseen vaikuttaviin tekijöihin ja työuran jatkamisen edistämiseen. Työ ja ihminen 19, 3, 307-325.

Schalk R, van Veldhoven M, de Lange AH, De Witte H, Kraus K, Stamov-Roßnagel C, Tordera N, van der Heijden B, Zappala' S, Bal M, Bertrand F, Claes R, Crego A, Dorenbosch L, de Jonge J, Desmette D, Gellert FJ, Hansez I, Iller C, Kooij D, Kuipers B, Linkola P, van den Broeck A, van der Schoot E, Zacher H (2010) Moving European research on work and ageing forward: Overview and agenda. European Journal of Work and Organizational Psychology 19, 1, 76-101.

Seppänen-Järvelä R, Aalto A-M, Juvonen-Posti P, Laaksonen M, Tuusa M (2015) Yksilöllisesti räätälöity ja työhön kytketty. Kelan kuntoutuksen kehittämishankkeen arviointitutkimus. Sosiaali-ja terveysturvan tutkimuksia 139. Kelan tutkimusosasto, Helsinki.

Shultz KS, Morton KR, Weckerle JR (1998) The Influence of Push and Pull Factors on Voluntary and Involuntary Early Retirees' Retirement Decision and Adjustment. Journal of Vocational Behaviour 53, 45-57.

Shultz KS, Wang M (2007) The influence of specific physical health conditions on retirement decisions. International Journal of Aging and Human Development 65, 2, 149-161. 
STM (2016) Kuntoutuksen uudistamiskomitean asettamispäätös. Sosiaali- ja terveysministeriö 33:00/2016.

Sulander J, Sinervo T, Elovainio M, Heponiemi T, Helkama K, Aalto A-M (2016) Does Organizational Justice Modify the Association Between Job Involvement and Retirement Intentions of Nurses in Finland? Research in Nursing \& Health 39, 5, 364-374.

Takala M, Karisalmi S, Tuominen E (2010) Tutkimuskatsaus. Teoksessa E Tuominen, M Takala, P Forma (toim.) Työolot ja työssä jatkaminen. Eläketurvakeskuksen tutkimuksia 2, 19-30. Eläketurvakeskus, Helsinki.

Talaga JA, Beehr TA (1995) Are there gender differences in predicting retirement decisions? Journal of Applied Psychology, 80, 1, 16-28.

Tuloksellisuustarkastuskertomus (2013) Kuntoutus työurien pidentäjänä. Valtiontalouden tarkastusviraston tarkastuskertomus 2, Helsinki.

Tuominen E, Takala M, Ahonen K, Karisalmi S (2010) Palkansaajien eläkeaikomukset 2000-luvulla. Teoksessa E Tuominen, M Takala, P Forma (toim.) Työolot ja työssä jatkaminen. Eläketurvakeskuksen tutkimuksia 2. Eläketurvakeskus, Helsinki.

Vainiemi K (2015) Kehittämisen helmet käytäntöön: AURA-kuntoutuksen synty ja "tuho". Kuntoutus 37, 3, 6-10.

van Solinge H, Henkens K (2014) Work-related factors as predictors in the retirement decision-making process of older workers in the Netherlands. Ageing and Society, 34, 9, 1551-1574
Vartiainen V (2009) Parantuuko työkyky - piteneekö työura? Seurantatutkimus vuonna 2005 Tyk-valmennukseen osallistuneista kuntoutujista Siuntion hyvinvointikeskuksessa. Miina Sillanpään säätiö, C:16, Helsinki.

von Bonsdorff M (2009) Intentions of early retirement and continuing to work among middle-aged and older employees. Jyväskylän yliopisto. Studies in Business and Economics 83, Jyväskylä.

von Bonsdorff ME, Huuhtanen P, Tuomi K, Seitsamo J (2009) Predictors of employees' early retirement intentions: an 11-year longitudinal study. Occupational Medicine 4, 59, 1-7.

Välimaa 0 (2011) Kategoriat ongelman selontekoina. Pitkäaikaistyöttömyydestä neuvotteleminen ja sen rakentuminen haastattelupuheessa. Acta Universitatis Tamperensis 1589, Tampereen Yliopistopaino Oy, Tampere.

Väänänen-Tomppo I (2010) Jotta jaksaisi ja jatkaisi työssä mahdollisimman pitkään. Teoksessa E Tuominen, M Takala, P Forma (toim.) Työolot ja työssä jatkaminen. Eläketurvakeskuksen tutkimuksia 2. Eläketurvakeskus, Helsinki.

Wang M, Shi J (2014) Psychological Research on Retirement. Annual Review of Psychology 65, 209233. 